medRxiv preprint doi: https://doi.org/10.1101/2021.06.28.21259423; this version posted July 3, 2021. The copyright holder for this preprint (which was not certified by peer review) is the author/funder, who has granted medRxiv a license to display the preprint in perpetuity.

All rights reserved. No reuse allowed without permission.

\title{
A prospective study of time-dependent exposures to childhood adversity and
}

\section{DNA methylation in childhood and adolescence}

Authors: $\quad$ Alexandre A. Lussier*1,2,3, Yiwen Zhu ${ }^{1,4}$, Brooke J. Smith ${ }^{1}$, Janine Cerutti ${ }^{1}$, Andrew J.

Simpkin ${ }^{5}$, Andrew D.A.C. Smith ${ }^{6}$, Matthew J. Suderman ${ }^{7}$, Esther Walton ${ }^{8}$, Kerry J.

Ressler $^{2,9}$, Erin C. Dunn**1,2,3,10

\section{Affiliations:}

${ }^{1}$ Psychiatric and Neurodevelopmental Genetics Unit, Centre for Genomic Medicine, Massachusetts General Hospital, Boston, MA, 02114, USA.

${ }^{2}$ Department of Psychiatry, Harvard Medical School, Boston, MA, 02115, USA.

${ }^{3}$ Stanley Center for Psychiatric Research, The Broad Institute of Harvard and MIT, Cambridge, MA, 02142, USA.

${ }^{4}$ Department of Epidemiology, Harvard T.H. Chan School of Public Health, Boston, MA, 02114, USA

${ }^{5}$ School of Mathematics, Statistics and Applied Mathematics, National University of Ireland, Galway, Ireland.

${ }^{6}$ Mathematics and Statistics Research Group, University of the West of England, Bristol, UK.

${ }^{7}$ MRC Integrative Epidemiology Unit, Population Health Sciences, Bristol Medical School, University of Bristol, Bristol, UK.

${ }^{8}$ Department of Psychology, University of Bath, Bath, UK.

${ }^{9}$ McLean Hospital, Belmont, MA, 02478, USA.

${ }^{10}$ Center on the Developing Child at Harvard University, Cambridge, MA, 02138, USA.

\section{Corresponding authors:}

*Alexandre A. Lussier: alussier[at]mgh.harvard.edu

**Erin C. Dunn: edunn2[at]mgh.harvard.edu

Keywords: $\quad$ ALSPAC, longitudinal, epigenetic, DNA methylation, childhood adversity, adolescence, trajectories. 
medRxiv preprint doi: https://doi.org/10.1101/2021.06.28.21259423; this version posted July 3, 2021. The copyright holder for this preprint

(which was not certified by peer review) is the author/funder, who has granted medRxiv a license to display the preprint in perpetuity.

All rights reserved. No reuse allowed without permission.

\section{ABSTRACT}

2 Background: Childhood adversity influences long-term health, particularly if experienced during

3 sensitive periods in development when physiological systems are more responsive to environmental influences. Although the underlying mechanisms remain unclear, prior studies suggest that DNA methylation (DNAm) may capture these time-dependent effects of childhood adversity. However, it remains unknown whether DNAm alterations persist into adolescence and how the timing of adversity might influence DNAm trajectories across development.

Methods: We examined the relationship between time-dependent adversity and genome-wide DNAm measured at three waves from birth to adolescence using prospective data from the Avon Longitudinal Study of Parents and Children. We first assessed the relationship between the timing of exposure to seven types of adversity (measured 5-8 times between ages 0-11) and DNAm at age 15 using a structured life course modeling approach. We also characterized the persistence into adolescence of associations identified from age 7 DNAm, as well as the influence of adversity on DNAm trajectories from ages $0-15$.

Results: Adversity was associated with differences in age 15 DNAm at 24 loci $(\mathrm{FDR}<0.05)$. Most loci (19 of 24) were associated with adversity (i.e., physical/sexual abuse, one-adult households, caregiver abuse) that occurred between ages 3-5. Although no DNAm differences present at age 7 persisted into adolescence, we identified seven unique types of DNAm trajectories across development, which highlighted diverse effects of childhood adversity on DNAm.

Conclusions: Our results suggest that childhood adversity, particularly between ages 3-5, can influence the trajectories of DNAm across development, exerting both immediate and latent effects on the epigenome. 
medRxiv preprint doi: https://doi.org/10.1101/2021.06.28.21259423; this version posted July 3, 2021. The copyright holder for this preprint (which was not certified by peer review) is the author/funder, who has granted medRxiv a license to display the preprint in perpetuity.

All rights reserved. No reuse allowed without permission.

\section{INTRODUCTION}

Childhood adversity, such as abuse or maltreatment $(1,2)$, family disruption or dysfunction (3, $4)$, or poverty $(5,6)$, is one of the most potent determinants of poor physical and mental health in both children and adults (7-9). While the mechanisms underlying the biological embedding of childhood adversity are not yet well understood, epigenetic processes, such as DNA methylation (DNAm), have emerged as one potential pathway to bridge genetic factors and life experiences (10). Large-scale population-based studies, systematic reviews, and meta-analyses have shown that DNAm signatures in humans are responsive to life experiences, including exposure to childhood adversity across the life course (11-16). However, prior studies on childhood adversity and DNAm have not fully explored two key dimensions of this relationship, which are critical to assess the biological risk posed by childhood adversity and to better target interventions for health promotion and disease prevention.

First, it remains unclear whether the timing of childhood adversity plays a role in shaping DNAm. Emerging evidence from human populations and animal models suggests there may be sensitive periods in epigenetic programming, when physiological and neurobiological systems may be primed for external influences, which can, in turn, impart more enduring effects on health (17-21). Few studies have investigated whether there are specific periods when childhood adversity may have greater effects on DNAm $(15,22)$, with no studies investigating epigenetic patterns in adolescence. Thus, it remains unknown whether there are sensitive periods during which adversity may exert greater influences on DNAm, and in turn on adolescent health.

Second, few studies have assessed the role of childhood adversity in relation to longitudinal measures of DNAm across development (i.e., DNAm trajectories). A recent review article argues that analyses examining DNAm at a single moment in development have limited capacity to identify robust associations with health outcomes due to the dynamic nature of epigenetic mechanisms (23). Rather, chrono-epigenetic patterns (i.e., the longitudinal dynamics of epigenetic processes) may more adequately predict the immediate and long-term effects of life experiences. To our knowledge, only six 
medRxiv preprint doi: https://doi.org/10.1101/2021.06.28.21259423; this version posted July 3, 2021. The copyright holder for this preprint

studies have assessed the influence of early-life experiences on the trajectories of DNAm across development. These have mainly focused on biological markers of prenatal environments, such as gestational age and birthweight (24), or have examined early-life stressors individually, including maternal pre-pregnancy BMI and gestational weight gain (25), prenatal maternal smoking (26), socioeconomic disadvantage during childhood $(27,28)$, and adolescent victimization (29). However, no study has examined how the timing of multiple types of childhood adversity may influence DNAm trajectories across development. Such knowledge would provide deeper insight into the molecular underpinnings of human health, while also help identify those at greater risk for the negative effects of adversity on health outcomes.

To address these gaps, we examined the longitudinal relationship between early-life adversity and genome-wide DNAm across childhood and adolescence, using data collected over two decades from a subsample of the Avon Longitudinal Study of Parents and Children (ALSPAC) cohort. Here, we examined the associations between exposure to seven types of childhood adversity, assessed repeatedly between birth and age 11, and DNAm at age 15. Given the unique availability of three waves of DNAm in this cohort (at birth, age 7, and age 15), we also examined DNAm trajectories from birth to adolescence. Our aims were to: 1) determine whether adolescent DNAm captured the time-dependent effects of childhood adversity; 2) characterize the developmental trajectories of DNAm linked to adversity; and 3) evaluate the persistence of previously-identified associations between adversity and DNAm in childhood (22). To our knowledge, this is the first study to investigate the time-dependent influences of childhood adversity on adolescent DNAm and trajectories of DNAm across development.

\section{MATERIALS AND METHODS}

\section{Sample}

Data came from the ALSPAC, a large population-based birth cohort from Avon, UK of 14,451 children followed from before birth through early adulthood (30, 31) (see Supplemental Materials for 
medRxiv preprint doi: https://doi.org/10.1101/2021.06.28.21259423; this version posted July 3, 2021. The copyright holder for this preprint (which was not certified by peer review) is the author/funder, who has granted medRxiv a license to display the preprint in perpetuity.

All rights reserved. No reuse allowed without permission.

details). The ALSPAC study website contains details of all the data available through a fully searchable data dictionary and variable search tool (http://www.bristol.ac.uk/alspac/researchers/our-data/). Ethical approval for the study was obtained from the ALSPAC Law and Ethics Committee and the Local Research Ethics Committees. Consent for biological samples was collected in accordance with the Human Tissue Act (2004). Informed consent for the use of data collected via questionnaires and clinics was obtained from participants following the recommendations of the ALSPAC Ethics and Law Committee. All data are available by request from the ALSPAC Executive Committee for researchers who meet the criteria for access to confidential data

(http://www.bristol.ac.uk/alspac/researchers/access/). Secondary analyses of ALSPAC data were approved with oversight by the Mass General Brigham Institutional Review Boards (IRB) (Protocol 2017P001110).

\section{Measures of childhood adversity}

We examined the effect of seven types of childhood adversity previously associated with DNAm (32-35): 1) caregiver physical or emotional abuse; 2) sexual or physical abuse (by anyone)(3639); 3) maternal psychopathology; 4) one adult in the household; 5) family instability; 6) financial hardship; and 7) neighborhood disadvantage. These adversities were generated from maternal reports via mailed questionnaires, collected 5-8 times between birth and age 11 (Figure 1; see Table S2 for a complete description of childhood adversities).

\section{DNAm data generation}

Blood-based DNAm profiles were generated at birth, age 7, and age 15 as part of the Accessible Resource for Integrated Epigenomics Studies (ARIES), a subsample of 1,018 mother-child pairs randomly selected from those with complete data across five or more waves of ALSPAC data collection (Supplemental Materials) (40). DNAm was measured at 485,577 CpG sites using the 
medRxiv preprint doi: https://doi.org/10.1101/2021.06.28.21259423; this version posted July 3, 2021. The copyright holder for this preprint (which was not certified by peer review) is the author/funder, who has granted medRxiv a license to display the preprint in perpetuity.

All rights reserved. No reuse allowed without permission.

Illumina Infinium HumanMethylation450 BeadChip microarray (Illumina, San Diego, CA). DNA for this assay was extracted from cord blood at birth, whole blood at age 7 , and peripheral blood leukocytes collected at age 15. Laboratory procedures, preprocessing analyses, and quality control steps performed have been described previously (40).

\section{DNA methylation data pre-processing and normalization}

DNAm data were processed using the meffil package in $\mathrm{R}$, which performs background correction and functional normalization of DNAm data (41). Twins and samples with $>10 \%$ of CpG sites with a detection $\mathrm{p}$-value $>0.01$ or a bead count $<3$ were removed, as were cross-hybridizing probes and polymorphic probes. To remove possible outliers, we winsorized the beta values (i.e., values that represent the percent of methylation at each $\mathrm{CpG}$ site), setting the bottom 5\% and top 5\% of values to the 5th and 95th quantile, respectively (42). Finally, we removed probes showing little variability across individuals, defined as CpGs with $<5 \%$ difference in DNAm between the $10^{\text {th }}$ and $90^{\text {th }}$ percentile of values. The final analytic sample after pre-processing consisted of 966 youths and 302,581 CpGs with DNAm data measured at age 15. DNAm measured at age 0 and 7 were similarly pre-processed and normalized (Supplemental materials).

\section{Covariates}

To account for potential confounding and be consistent with previous work on childhood adversities (15), we included the following covariates: age of blood collection, sex, race/ethnicity, maternal age at birth, maternal education at birth, birthweight, number of previous pregnancies, maternal smoking during pregnancy, and cell type proportions estimated using the Houseman method (43). See Supplemental Materials for variable coding.

\section{Analyses}


medRxiv preprint doi: https://doi.org/10.1101/2021.06.28.21259423; this version posted July 3, 2021. The copyright holder for this preprint (which was not certified by peer review) is the author/funder, who has granted medRxiv a license to display the preprint in perpetuity.

All rights reserved. No reuse allowed without permission.

\section{Structured Life Course Modeling Approach (SLCMA)}

Our primary analyses focused on identifying time-dependent associations between each type of childhood adversity and DNAm measured in adolescence (age 15). To identify these associations, we used the structured life course modeling approach (SLCMA; pronounced "slick-mah"), which is a twostage method that simultaneously compares different a priori-specified hypotheses that explain exposure-outcome relationships (44-46). The SLCMA uses variable selection to identify the life course hypothesis explaining the greatest proportion of outcome variation. Estimates confidence intervals and p-values are calculated for the selected life course hypothesis, using post-selective inference to remove bias associated with multiple testing and variable selection. The SLCMA has been successfully applied to high-dimensional DNAm data to identify sensitive periods in development that can influence genome-wide DNAm patterns $(15,22,47)$.

We tested time-dependent exposure to adversity for the timepoint shown in Figure 1. We interpreted exposure to each adversity type through six separate life course hypotheses, including four sensitive periods hypotheses that encoded exposure to each childhood adversity during: 1) very early childhood (ages 0-2), 2) early childhood (ages 3-5), 3) middle childhood (ages 6-7), 4) late childhood (ages 8-11); and two additive hypotheses: 5) total number exposures across childhood (accumulation), and 6) total number of exposures weighted by age (recency), which allowed us to assess if more recent exposures had a stronger impact than distal exposures.

We used selective inference to perform post-selection inference (48) and adjusted for covariates using the Frisch-Waugh-Lovell theorem (49), which has been shown to improve statistical power in penalized regression analyses $(47,50)$. Only complete cases (i.e., individuals with non-missing data on covariates and exposures from ages 0-11) were analyzed for each adversity (Figure 1). We accounted for multiple-testing using the Benjamini-Hochberg method to control the false-discovery rate at 5\% $(\mathrm{FDR}<0.05)(51)$, or a Bonferroni-corrected threshold of $\mathrm{p}<1.65 \times 10^{-7}$. 
medRxiv preprint doi: https://doi.org/10.1101/2021.06.28.21259423; this version posted July 3, 2021. The copyright holder for this preprint (which was not certified by peer review) is the author/funder, who has granted medRxiv a license to display the preprint in perpetuity.

All rights reserved. No reuse allowed without permission.

Functional analyses of SLCMA results

We investigated the biological implications of our findings from the SLCMA in four different ways. First, we assessed the enrichment of regulatory elements in top loci compared to the all analyzed loci using chi-squared tests. Second, we examined the correlation of DNAm at the top loci in blood and four different brain regions using the Blood Brain DNA Methylation Comparison Tool (52). Third, we analyzed the enrichment of biological processes in top loci using gene ontology (GO) terms from the DAVID tool $(53,54)$. Fourth, we assessed the evolutionary constraint of genes linked to top loci using data from the Exome Aggregation Consortium (55).

\section{Trajectories of DNAm response to childhood adversity}

The three waves of longitudinal DNAm data available for the ALSPAC cohort provide a unique opportunity to investigate the developmental patterns of DNAm across development. Building from the SLCMA findings, we pursued three additional sets of analyses.

\section{Pre-existence of age 15 associations}

First, we determined whether DNAm differences present at age 15 emerged earlier in development. Using linear regression, we tested whether exposure to the adversity selected in the SLCMA at age 15 was associated with DNAm at the same top loci at birth or age 7 , while adjusting for covariates.

\section{Types of DNAm trajectories across development}

Second, we investigated patterns of DNAm change beyond differences between single time points, focusing on patterns of change and stability among the top loci identified from the SLCMA of age 15 DNAm. Specifically, we examined the longitudinal DNAm patterns of individuals in three distinct exposure groups: 1) adversity exposure during the period identified from the SLCMA (labeled 
medRxiv preprint doi: https://doi.org/10.1101/2021.06.28.21259423; this version posted July 3, 2021. The copyright holder for this preprint (which was not certified by peer review) is the author/funder, who has granted medRxiv a license to display the preprint in perpetuity.

All rights reserved. No reuse allowed without permission.

173

as exposed-SP); 2) adversity exposure outside the period identified from the SLCMA (exposed-other);

and 3) never exposed. We then performed an ANOVA of the statistical interaction between age at DNAm collection and exposure group, controlling for DNAm repeated measures in the ANOVA as fixed effects, which allowed us to determine whether any exposure group differed from another in its longitudinal DNAm trajectory. Loci showing significant differences for group-by-age interactions $(\mathrm{FDR}<0.05)$ were carried forward into the next stage, as they showed more granular differences between exposure groups across development.

From these loci, we identified groupings of loci with similar longitudinal patterns (i.e., types of DNAm trajectories). Similarities were defined in relation to three main distinguishing features: 1) mean exposure group differences across ages 2) mean age differences across exposure groups, and 3) exposure group differences within each age. These features were determined using Tukey post-hoc analyses of the ANOVA described above. We then performed hierarchical clustering of these features to identify homogeneous subsets of trajectories (Supplemental materials).

\section{Persistence of childhood DNAm differences to adolescence}

Third, we assessed whether DNAm alterations linked to childhood adversity, which we previously identified at age 7 (22), persisted until adolescence. For these analyses, we performed linear models between adversity and age 15 DNAm data for these 48 childhood loci only (Supplemental materials).

\section{RESULTS}

\section{Sample characteristics and prevalence of exposure to adversity}

Demographic characteristics of the ARIES sample and subset of children with any exposure to adversity between ages 0-11 can be found in Table S1. The prevalence of exposure to a given adversity between the ages of $0-11$ ranged from $15.1 \%$ (sexual/physical abuse) to $34.8 \%$ (maternal 
medRxiv preprint doi: https://doi.org/10.1101/2021.06.28.21259423; this version posted July 3, 2021. The copyright holder for this preprint (which was not certified by peer review) is the author/funder, who has granted medRxiv a license to display the preprint in perpetuity.

All rights reserved. No reuse allowed without permission.

psychopathology) (Figure S1; Table S3). The correlation of exposure within each adversity across different developmental ages ranged from 0.36 (family instability) to 0.786 (one adult in the household). The different types of adversity were weakly correlated with each other, ranging from an average correlation of -0.04 (family instability) to 0.16 (maternal psychopathology), suggesting that these measures of childhood adversity captured distinct exposures.

\section{Childhood adversity showed time-dependent associations with adolescent DNAm profiles}

Across all types of adversity, 24 loci showed significant associations between exposure to adversity and DNAm levels at age 15 at $\mathrm{FDR}<0.05 ; 7$ of these loci were also significant at a Bonferroni-corrected p-value $<1.65 \times 10^{-7}$ (Table 1).

Among FDR-significant loci, sensitive period models were most often selected, with 21 loci showing associations with childhood adversity that occurred during very early childhood ( 2 of 24$)$, early childhood (18 of 24), or late childhood (1 of 24) (Figure 2A). By contrast, only 3 loci showed associations with the accumulation of adversity across development.

A large proportion of effects were for one-adult households in the FDR-significant loci (18 of 24 loci). We also identified associations with caregiver physical/emotional abuse (2 loci), sexual or physical abuse by anyone (3 loci), and maternal psychopathology (1 locus). No associations were observed with family instability or neighborhood disadvantage.

Exposure to adversity was most often associated with a decrease in DNAm levels (21 out of 24). On average, childhood adversity exposure was linked to a 3.6\% absolute difference in DNA methylation levels (range 1.5-10.4\%). For the three loci associated with accumulated time with one adult in the household, each additional timepoint with one adult was associated with a $1 \%$ difference in DNAm (range 0.3-1.4\%). 
medRxiv preprint doi: https://doi.org/10.1101/2021.06.28.21259423; this version posted July 3, 2021. The copyright holder for this preprint (which was not certified by peer review) is the author/funder, who has granted medRxiv a license to display the preprint in perpetuity.

All rights reserved. No reuse allowed without permission.

To further understand the biological implications of loci associated with childhood adversity,

we assessed their genomic context, relationship with brain DNA methylation levels, and functional relevance at the biological and evolutionary level (Table S4).

From a genomic enrichment standpoint, the 24 FDR-significant loci were overrepresented in enhancers $\left(\chi^{2}=5.1 ; p=0.025\right)$ but not in gene promoters $\left(\chi^{2}=2.1 ; p=0.15\right.$; Figure S2A $)$ away from CpG islands ('Open Sea') but not in CpG Islands, shores, or shelves $\left(\chi^{2}=13.7 ; p=0.018\right.$; Figure S2B).

Overall, the top loci identified in adolescence tended to show higher representation in regions of lower CpG density, suggesting these genomic regions may be more responsive to childhood adversity. Most loci (19/24) had weak, but positive correlations between brain and blood (prefrontal cortex $r_{a v g}=0.06$, range $=-0.19-0.65$; entorhinal cortex $r_{a v g}=0.07$, range $=-0.23-0.60$; superior temporal gyrus $r_{a v g}=0.06$, range $=-0.18-0.61$; cerebellum $r_{a v g}=0.07$, range=-0.13-0.54) $($ Table S5; Figure S3). Thus, adversity-induced alterations to blood DNAm levels may reflect similar changes in the central nervous system.

We also identified 6 distinct clusters of biological processes overrepresented in FDR-significant loci ( $\mathrm{n}=24$ genes). Although none reached statistical significance, these clusters were broadly implicated in muscle tissue development, cell adhesion, MAPK cascades, and cellular regulation of biosynthetic processes (Figure S4). These results suggest that different types of childhood adversity may act through diverse biological process to influence a multitude of downstream biological processes, rather than through a concerted network of biological pathways.

Genes linked to FDR-significant loci showed little evidence of strong evolutionary conservation overall, as measured by the intolerance to loss-of-function estimates (Table S4; Figure S5). However, 3 genes showed high probability of intolerance to genetic variation resulting in their loss-of-function ( $\mathrm{pLI}>0.9 ; D S P, C U X 2$, and $S T K 38 L$ ), which were all linked to the accumulation of exposure to one 
medRxiv preprint doi: https://doi.org/10.1101/2021.06.28.21259423; this version posted July 3, 2021. The copyright holder for this preprint (which was not certified by peer review) is the author/funder, who has granted medRxiv a license to display the preprint in perpetuity.

All rights reserved. No reuse allowed without permission.

246 adult in the household. These findings highlight a potential role for genes influenced by parental and

247 social environment in human survival and evolution.

\section{DNAm differences at age 15 were not present earlier in childhood}

Among the 24 FDR-significant loci observed in DNAm at age 15, three associations were

observed with DNAm at birth (Table S6) and two with DNAm at age $7(\mathrm{p}<0.05)$ (Table S7). However,

none of these association survived adjustment for multiple tests ( 24 tests at FDR $<5 \%$ ), and effect

estimates were considerably smaller at age 7 than at age 15 with consistent direction for less than half

(11 of 24) (Figure 3A).

\section{Childhood adversity was linked to distinct trajectories of DNAm across development}

Moving beyond single time points of DNAm, we found that 21 of the 24 FDR-significant loci

had significant adversity exposure group-by-age interactions (FDR $<0.05$ ), suggestive of more complex

patterns of change and stability across development. From these loci, we further identified six types of

longitudinal DNAm trajectories, which showed distinct differences in DNAm patterns across ages and

adversity exposure groups, both across and within specific ages (Figure 3; Table 1; Figure S6; Table

S8). For the three loci that did not show exposure group-by-age interactions, we identified slight

differences between exposed-SP and unexposed youths at age 7, which fully emerged by age 15 (i.e.,

stable). Table 2 provides a full description of the patterns that distinguish these different types of

DNAm trajectories, as well as examples.

\section{Associations between adversity and childhood DNAm did not persist into adolescence}

We previously identified associations between time-varying adversity exposures before age 7 
medRxiv preprint doi: https://doi.org/10.1101/2021.06.28.21259423; this version posted July 3, 2021. The copyright holder for this preprint (which was not certified by peer review) is the author/funder, who has granted medRxiv a license to display the preprint in perpetuity.

All rights reserved. No reuse allowed without permission.

age 15 . Of these $48 \mathrm{CpG}$ sites, only one showed an association between childhood adversity and DNAm at age $15(\mathrm{p}<0.05$; Table S9). However, this association did not survive adjustment for multiple tests (48 tests at an FDR $<0.05)$, with just over half showing consistent direction of effect $(25 / 48)$

(Figure 3D).

\section{DISCUSSION}

The main finding from this study is that childhood adversity has unique and time-dependent associations with DNAm, which manifest through varying patterns of persistence and latency across development. This work highlights the role of sensitive periods in development and their effects on chrono-epigenetic patterns. To our knowledge, this is the first study to incorporate time-dependent measures of adversity in the study of longitudinal epigenetic patterns.

Our findings point to early childhood (i.e., between the ages of 3 and 5) as a sensitive period for the biological embedding of childhood adversity, as reflected by DNAm differences present in adolescence. These findings are consistent with multiple prior studies in humans $(13,15)$ and animal models $(56,57)$, which have shown that exposures earlier in life may have greater influence on epigenetic patterns. This emphasis on sensitive periods, over other alternative life course hypotheses, is also in line with previous analyses of childhood adversity and DNAm in the ALSPAC cohort, which found that most sensitive period effects arose from exposures during early childhood (22). Early childhood (between ages 3-5) is a critical time period when children begin rapidly developing cognitive, social, emotional, linguistic, and regulatory skills (58). As developmental processes during preschool ages provide an important foundation for future executive functioning (59), this period is ripe for interventions that may limit or prevent the long-term effects of childhood adversity. Indeed, prior studies on children exposed to domestic violence have shown that child-parent psychotherapy between age 3-5 can improve PTSD and depressive symptoms, as well as child behavior problems $(60,61)$. 
medRxiv preprint doi: https://doi.org/10.1101/2021.06.28.21259423; this version posted July 3, 2021. The copyright holder for this preprint (which was not certified by peer review) is the author/funder, who has granted medRxiv a license to display the preprint in perpetuity.

All rights reserved. No reuse allowed without permission.

294 Recent evidence also suggests that interventions that promote executive function skills may help build

295 resilience among preschool children exposed to adversity and help build toward future success (62).

Of the seven types of adversity examined, exposure to single parent households had the greatest

number of associations in adolescence. By contrast, previous research on DNAm from the same

children at age 7 identified no associations with one-adult households, suggesting that these effects

may be adolescent-specific (22). Single parent family structures are associated with onset of puberty, as

well as other mental health outcomes such as self-esteem, depressive symptoms, and externalizing

behaviors, especially in girls (64-66) and when exposure occurs during the first few years of life (67).

This relationship may reflect an increased likelihood of children in one-adult household to form

maladaptive attachment styles (64), or result from the decreased emotional and material support that

can be provided by single parents due to societal and financial pressures. In turn, these gaps in expected

versus experienced inputs in early life could manifest during adolescence, a period of rapid maturation

for higher order functions. Our findings suggest the biological effects of one-adult households may

extend to the DNAm level, which could potentially influence developmental and health outcomes in

adolescence. Curiously, fewer associations were observed for other adversities, such as maternal

psychopathology and experiences of sexual, physical, or emotional abuse. These adversities may have

subtler influences on the adolescent epigenome, which require larger sample sizes or meta-analyses to

uncover associations. Of note, none of our top loci overlapped between different types of childhood

adversity, nor were they present in a previous study of DNAm trajectories and adolescent victimization

(29). These results provide additional insight into ongoing debate on the "lumping or splitting" of

childhood adversities in clinical research (68), showing that distinct dimensions of adversity may result 
medRxiv preprint doi: https://doi.org/10.1101/2021.06.28.21259423; this version posted July 3, 2021. The copyright holder for this preprint (which was not certified by peer review) is the author/funder, who has granted medRxiv a license to display the preprint in perpetuity.

All rights reserved. No reuse allowed without permission.

318 highlighting the need for studies that compare and contrast the effects of adversity on both epigenetic

319 mechanisms and health outcomes.

Arguably the most novel set of findings from our study concerned the relationships of adversity

and patterns of stability and change in DNAm over time. Most DNAm trajectories showed primarily

latent effects of adversity, meaning they did not emerge until age 15 in youths exposed to adversity.

These findings are in line with previous longitudinal studies of genome-wide DNAm, which have

shown that early-life stressors, such as prenatal maternal smoking (26) and socio-economic

disadvantage during childhood $(27,28)$, can have both immediate and latent effects on DNAm during

childhood and adolescence. However, some trajectories also showed effects that emerged at earlier

ages, which may reflect a desynchronization of epigenetic patterns in response to childhood adversity

that became more apparent later in development. Importantly, Oh and Petronis recently suggested that

these "sleeper" temporal rhythms in DNAm may explain why complex diseases unfold over years of

development, rather than immediately after exposures or risk factors (23). Alternatively, these

alterations could reflect specific development windows when the impacts of adversity on biological

processes may begin to emerge. These findings suggest the effects of childhood adversity on the

epigenome may not instantly take effect, but rather remain latent or alter the developmental trajectories

of DNAm in subtle ways that evade immediate detection. As such, future research should investigate

whether these latent effects of childhood adversity on the epigenome persist into adulthood and

whether they are indeed more likely to influence physical and mental health than alterations that arise earlier in development. 
medRxiv preprint doi: https://doi.org/10.1101/2021.06.28.21259423; this version posted July 3, 2021. The copyright holder for this preprint (which was not certified by peer review) is the author/funder, who has granted medRxiv a license to display the preprint in perpetuity.

All rights reserved. No reuse allowed without permission.

DNAm signatures of prenatal smoking persist across development, suggesting that exposures with

more clearly delineated biological responses may induce more lasting consequences on the epigenome

(26). Although these findings suggest that early signatures of childhood adversity may fade from the

epigenome, these short-term alterations may alter the developmental trajectories of downstream

physiological systems or cellular pathways, which may not be reflected in the epigenome despite their

potential influences on health and disease (69). An alternative hypothesis is that the effects of adversity

may indeed resolve over time, suggestive of adaptive alterations to the epigenome across development,

without the need for focused interventions. Although these findings may have important ramifications

for the prevention and treatment of adversity-related health conditions, additional research is needed to

identify the true consequences of these differences and determine whether short- and/or long-term

DNAm changes mediate the link between childhood adversity and health outcomes.

tissue types at each wave, which may have induced additional variability between ages. Although we

corrected for cell type composition using well-established bioinformatic methods, differences in

DNAm between waves may have been partially driven by tissue-based differences. As such, additional

research using consistent tissues for DNAm measurement across development are needed to fully parse

the longitudinal effects of adversity on DNAm. Furthermore, we were unable to assess the effects of childhood adversity on the types of DNAm trajectories across development, as the timing of DNAm and adversity overlapped. Future studies with additional waves of DNAm after the measurement of childhood adversity may help untangle the role of adversity in shaping trajectories of DNAm, as would the use of causal inference methods that can handle time-varying exposures and confounders (70).

Finally, our analytic subset was mainly composed of children from European descent and families with socioeconomic privilege, limiting the generalizability of our findings to broader populations, given existing disparities in distributions of childhood adversity and health outcomes (71). Our findings 
medRxiv preprint doi: https://doi.org/10.1101/2021.06.28.21259423; this version posted July 3, 2021. The copyright holder for this preprint (which was not certified by peer review) is the author/funder, who has granted medRxiv a license to display the preprint in perpetuity.

All rights reserved. No reuse allowed without permission.

should be replicated in more diverse cohorts to fully assess the impact of childhood adversity on DNAm across development.

\section{CONCLUSIONS}

In sum, this study highlights the complex relationship between childhood adversity and longitudinal DNAm trajectories across development, which vary not only based on the timing of adversity, but also the age at which DNAm is measured. Our findings also provide further insight into the sensitive periods that shape the biological embedding of experiences during early-life, while placing further emphasis on the analysis of chrono-epigenetic patterns in the context of human health. In particular, our results suggest that adversity during early childhood may alter the overall trajectory of DNAm across development, which may, in turn, influence health across the life course. As such, future studies should continue to investigate longitudinal measures of DNAm to identify the potential role of latent and occasionally persistent epigenetic alterations in driving short- and long-term health outcomes. Ultimately, this line of research will help guide intervention strategies and identify individual who are at higher risk for physical and mental disorders arising from exposure to childhood adversity.

\section{ACKNOWLEDGEMENTS}

This work was supported by the National Institute of Mental Health of the National Institutes of Health (grant number R01MH113930 awarded to ECD). The content is solely the responsibility of the authors and does not necessarily represent the official views of the National Institutes of Health. Dr. Dunn and Dr. Lussier were also supported by a grant from One Mind. We are extremely grateful to all the families who took part in the ALSPAC study, the midwives for their help in recruiting them, and the whole ALSPAC team, which includes interviewers, computer and laboratory technicians, clerical workers, research scientists, volunteers, managers, receptionists and nurses. The UK Medical Research 
medRxiv preprint doi: https://doi.org/10.1101/2021.06.28.21259423; this version posted July 3, 2021. The copyright holder for this preprint (which was not certified by peer review) is the author/funder, who has granted medRxiv a license to display the preprint in perpetuity.

All rights reserved. No reuse allowed without permission.

393 Council and Wellcome (Grant ref: 217065/Z/19/Z) and the University of Bristol provide core support

394 for ALSPAC. A comprehensive list of grants funding is available on the ALSPAC website

395 (http://www.bristol.ac.uk/alspac/external/documents/grant-acknowledgements.pdf); This research was

396 specifically funded by grants from the BBSRC (BBI025751/1; BB/I025263/1), IEU

397 (MC_UU_12013/1; MC_UU_12013/2; MC_UU_12013/8), National Institute of Child and Human

398 Development (R01HD068437), NIH (5RO1AI121226-02), and CONTAMED EU (212502). This

399 publication is the work of the authors, whom will serve as guarantors for the contents of this paper.

400 Dr. Walton is funded by CLOSER, whose mission is to maximise the use, value and impact of

401 longitudinal studies (www.closer.ac.uk). CLOSER was funded by the Economic and Social Research

402 Council (ESRC) and the Medical Research Council (MRC) between 2012 and 2017. Its initial five-year

403 grant has since been extended to March 2021 by the ESRC (grant reference: ES/K000357/1). The

404 funders took no role in the design, execution, analysis or interpretation of the data or in the writing up

405 of the findings. Dr. Walton is also supported by the European Union's Horizon 2020 research and

406 innovation programme (grant $\left.\mathrm{n}^{\circ} 848158\right)$.

407 Finally, we would also like to thank Dr. Garrett Fitzmaurice for his guidance in the characterization of

408 DNAm trajectories across development.

409

410 CONFLICTS OF INTEREST

411 The authors have no conflicts of interest to declare. 
medRxiv preprint doi: https://doi.org/10.1101/2021.06.28.21259423; this version posted July 3, 2021. The copyright holder for this preprint (which was not certified by peer review) is the author/funder, who has granted medRxiv a license to display the preprint in perpetuity.

All rights reserved. No reuse allowed without permission.

412

413

414

415

416

417

418

419

420

421

422

423

424

425

426

427

428

429

430

431

432

433

434

435

436

437

438

439

440

441

442

443

444

445

446

447

448

449

450

451

452

453

454

455

456

457

458

459

460

461

462

463

\section{REFERENCES}

1. Slopen N, Koenen KC, Kubzansky LD. Cumulative adversity in childhood and emergent risk factors for long-term health. Journal of Pediatrics. 2014;164(3):631-8.

2. Widom CS, DuMont K, Czaja SJ. A prospective investigation of major depressive disorder and comorbidity in abused and neglected children grown up. Archives of General Psychiatry. 2007;64:49-56.

3. Repetti RL, Taylor SE, Seeman TE. Risky families: Family social environments and the mental and physical health of offspring. Psychological Bulletin. 2002;128(2):330-66.

4. Gilman SE, Kawachi I, Fitzmaurice GM, Buka SL. Family disruption in childhood and risk of adult depression. American Journal of Psychiatry. 2003;160:939-46.

5. Brooks-Gunn J, Duncan GJ. Effects of poverty on children. The Future of Children. 1997;7(2):55-71.

6. McLeod JD, Shanahan MJ. Trajectories of poverty and children's mental health. Journal of Health and Social Behavior. 1996;37(3):207-20.

7. McLaughlin KA, Green JG, Gruber MJ, Sampson NA, Zaslavsky AM, Kessler RC. Childhood adversities and adult psychiatric disorders in the National Comorbidity Survey Replication II: Associations with persistence of DSM-IV disorders. Archives of General Psychiatry. 2010;67(2):124-32.

8. McLaughlin KA, Green JG, Gruber MJ, Sampson NA, Zaslavsky AM, Kessler RC. Childhood adversities and first onset of psychiatric disorders in a national sample of US adolescents. JAMA Psychiatry. 2012;69(11):1151-60.

9. Gilman SE, Ni MY, Dunn EC, Breslau J, McLaughlin KA, Smoller JW, et al. Contributions of the social environment to first-onset and recurrent mania. Mol Psychiatry. 2015;20(3):329-36.

10. Aristizabal MJ, Anreiter I, Halldorsdottir T, Odgers CL, McDade TW, Goldenberg A, et al. Biological embedding of experience: A primer on epigenetics. Proceedings of the National Academy of Sciences. 2020;117(38):23261.

11. Cecil CAM, Zhang Y, Nolte T. Childhood maltreatment and DNA methylation: A systematic review. Neuroscience \& Biobehavioral Reviews. 2020;112:392-409.

12. Parade SH, Huffhines L, Daniels TE, Stroud LR, Nugent NR, Tyrka AR. A systematic review of childhood maltreatment and DNA methylation: candidate gene and epigenome-wide approaches. Translational Psychiatry. 2021;11(1):134.

13. Essex MJ, Boyce WT, Hertzman C, Lam LL, Armstrong JM, Neumann SM, et al. Epigenetic vestiges of early developmental adversity: childhood stress exposure and DNA methylation in adolescence. Child Development. 2013;84(1):58-75.

14. Yang BZ, Zhang H, Ge W, Weder N, Douglas-Palumberi H, Perepletchikova F, et al. Child abuse and epigenetic mechanisms of disease risk. Am J Prev Med. 2013;44(2):101-7.

15. Dunn EC, Soare TW, Zhu Y, Simpkin AJ, Suderman MJ, Klengel T, et al. Sensitive periods for the effect of childhood adversity on DNA methylation: results from a prospective, longitudinal study. Biological Psychiatry. 2019;85(10):838-49.

16. Klengel T, Mehta D, Anacker C, Rex-Haffner M, Pruessner JC, Pariante CM, et al. Allele-specific FKBP5 DNA demethylation mediates gene-childhood trauma interactions. Nat Neurosci. 2013;16(1):33-41.

17. Bornstein MH. Sensitive periods in development: Structural characteristics and causal interpretations. Psychological Bulletin. 1989;105(2):179-97.

18. Ben-Shlomo Y, Kuh D. A life course approach to chronic disease epidemiology: conceptual models, empirical challenges, and interdisciplinary perspectives. Int J Epidemiol. 2002;31(2):285-93.

19. Knudsen E. Sensitive periods in the development of the brain and behavior. J Cogn Neurosci. 2004;16:1412-25.

20. Shonkoff JP, Boyce WT, McEwen BS. Neuroscience, molecular biology, and the childhood roots of health disparities. JAMA. 2009;301(21):2252-9.

21. Zeanah CH, Gunnar MR, McCall RB, Kreppner JM, Fox NA. Sensitive periods. Monogr Soc Res Child Dev. 2011;76(4):147-62.

22. Lussier AA, Zhu Y, Smith BJ, Simpkin AJ, Smith ADAC, Suderman MJ, et al. Updates to data versions and analytic methods influence the reproducibility of results from epigenome-wide association studies. bioRxiv. 2021:2021.04.23.441014.

23. Oh ES, Petronis A. Origins of human disease: the chrono-epigenetic perspective. Nat Rev Genet. 2021. 
medRxiv preprint doi: https://doi.org/10.1101/2021.06.28.21259423; this version posted July 3, 2021. The copyright holder for this preprint (which was not certified by peer review) is the author/funder, who has granted medRxiv a license to display the preprint in perpetuity.

All rights reserved. No reuse allowed without permission.

24. Simpkin AJ, Hemani G, Suderman M, Gaunt TR, Lyttleton O, McArdle WL, et al. Prenatal and early life influences on epigenetic age in children: a study of mother-offspring pairs from two cohort studies. Human Molecular Genetics. 2016;25(1):191-201.

25. Sharp GC, Lawlor DA, Richmond RC, Fraser A, Simpkin A, Suderman M, et al. Maternal pre-pregnancy BMI and gestational weight gain, offspring DNA methylation and later offspring adiposity: findings from the Avon Longitudinal Study of Parents and Children. Int J Epidemiol. 2015;44(4):1288-304.

26. Richmond RC, Simpkin AJ, Woodward G, Gaunt TR, Lyttleton O, McArdle WL, et al. Prenatal exposure to maternal smoking and offspring DNA methylation across the lifecourse: findings from the Avon Longitudinal Study of Parents and Children (ALSPAC). Hum Mol Genet. 2015;24(8):2201-17.

27. Alfano R, Guida F, Galobardes B, Chadeau-Hyam M, Delpierre C, Ghantous A, et al. Socioeconomic position during pregnancy and DNA methylation signatures at three stages across early life: epigenomewide association studies in the ALSPAC birth cohort. Int J Epidemiol. 2019;48(1):30-44.

28. Laubach ZM, Perng W, Cardenas A, Rifas-Shiman SL, Oken E, DeMeo D, et al. Socioeconomic status and DNA methylation from birth through mid-childhood: a prospective study in Project Viva. Epigenomics. 2019;11(12):1413-27.

29. Kandaswamy R, Hannon E, Arseneault L, Mansell G, Sugden K, Williams B, et al. DNA methylation signatures of adolescent victimization: analysis of a longitudinal monozygotic twin sample. Epigenetics. 2020:1-18.

30. Fraser A, Macdonald-Wallis C, Tilling K, Boyd A, Golding J, Davey Smith G, et al. Cohort Profile: the Avon Longitudinal Study of Parents and Children: ALSPAC mothers cohort. Int J Epidemiol. 2013;42(1):97-110.

31. Boyd A, Golding J, Macleod J, Lawlor DA, Fraser A, Henderson J, et al. Cohort Profile: the 'children of the 90s'--the index offspring of the Avon Longitudinal Study of Parents and Children. Int J Epidemiol. 2013;42(1):111-27.

32. Cunliffe VT. The epigenetic impacts of social stress: how does social adversity become biologically embedded? Epigenomics. 2016;8(12):1653-69.

33. Vaiserman AM, Koliada AK. Early-life adversity and long-term neurobehavioral outcomes: epigenome as a bridge? Human genomics. 2017;11(1):34.

34. Eachus H, Cunliffe VT. Biological Embedding of Psychosocial Stress Over the Life Course. Epigenetics of Aging and Longevity: Elsevier; 2018. p. 251-70.

35. McLaughlin KA. Future directions in childhood adversity and youth psychopathology. Journal of Clinical Child \& Adolescent Psychology. 2016;45(3):361-82.

36. Provenzi L, Giorda R, Beri S, Montirosso R. SLC6A4 methylation as an epigenetic marker of life adversity exposures in humans: a systematic review of literature. Neuroscience \& Biobehavioral Reviews. 2016;71:7-20.

37. Ramo-Fernández L, Schneider A, Wilker S, Kolassa IT. Epigenetic alterations associated with war trauma and childhood maltreatment. Behavioral sciences \& the law. 2015;33(5):701-21.

38. Tomassi S, Tosato S. Epigenetics and gene expression profile in First-Episode Psychosis: the role of Childhood Trauma. Neuroscience \& Biobehavioral Reviews. 2017.

39. Tyrka AR, Ridout KK, Parade SH. Childhood adversity and epigenetic regulation of glucocorticoid signaling genes: Associations in children and adults. Development and psychopathology. 2016;28(4pt2):1319-31.

40. Relton CL, Gaunt T, McArdle W, Ho K, Duggirala A, Shihab H, et al. Data Resource Profile: Accessible Resource for Integrated Epigenomic Studies (ARIES). Int J Epidemiol. 2015;44(4):1181-90.

41. Min JL, Hemani G, Davey Smith G, Relton C, Suderman M. Meffil: efficient normalization and analysis of very large DNA methylation datasets. Bioinformatics (Oxford, England). 2018;34(23):3983-9.

42. Tukey JW. The Future of Data Analysis. The Annals of Mathematical Statistics. 1962;33(1):1-67.

43. Houseman EA, Molitor J, Marsit CJ. Reference-free cell mixture adjustments in analysis of DNA methylation data. Bioinformatics. 2014;30.

44. Mishra G, Nitsch D, Black S, De Stavola B, Kuh D, Hardy R. A structured approach to modelling the effects of binary exposure variables over the life course. Int J Epidemiol. 2009.

45. Smith ADAC, Hardy R, Heron J, Joinson CJ, Lawlor DA, Macdonald-Wallis C, et al. A structured approach to hypotheses involving continuous exposures over the life course. Int J Epidemiol. 2016. 
medRxiv preprint doi: https://doi.org/10.1101/2021.06.28.21259423; this version posted July 3, 2021. The copyright holder for this preprint (which was not certified by peer review) is the author/funder, who has granted medRxiv a license to display the preprint in perpetuity.

All rights reserved. No reuse allowed without permission.

46. Smith ADAC, Heron J, Mishra G, Gilthorpe MS, Ben-Shlomo Y, Tilling K. Model Selection of the Effect of Binary Exposures over the Life Course. Epidemiology. 2015.

47. Zhu Y, Simpkin AJ, Suderman MJ, Lussier AA, Walton E, Dunn EC, et al. A Structured Approach to Evaluating Life Course Hypotheses: Moving Beyond Analyses of Exposed Versus Unexposed in the Omics Context. Am J Epidemiol. 2020.

48. Tibshirani RJ, Taylor J, Lockhart R, Tibshirani R. Exact Post-Selection Inference for Sequential Regression Procedures. Journal of the American Statistical Association. 2016;111(514):600-20.

49. Frisch R, Waugh VF. Partial Time Regressions as Compared with Individual Trends. Econometrica. 1933.

50. Yamada H. The Frisch-Waugh-Lovell theorem for the lasso and the ridge regression. Communications in Statistics - Theory and Methods. 2017;46(21):10897-902.

51. Benjamini Y, Hochberg Y. Controlling the False Discovery Rate: A Practical and Powerful Approach to Multiple Testing. Journal of the Royal Statistical Society Series B (Methodological). 1995;57(1):289 300.

52. Hannon E, Lunnon K, Schalkwyk L, Mill J. Interindividual methylomic variation across blood, cortex, and cerebellum: implications for epigenetic studies of neurological and neuropsychiatric phenotypes. Epigenetics. 2015;10(11):1024-32.

53. Huang da W, Sherman BT, Lempicki RA. Systematic and integrative analysis of large gene lists using DAVID bioinformatics resources. Nat Protoc. 2009;4(1):44-57.

54. Huang da W, Sherman BT, Lempicki RA. Bioinformatics enrichment tools: paths toward the comprehensive functional analysis of large gene lists. Nucleic Acids Res. 2009;37(1):1-13.

55. Lek M, Karczewski KJ, Minikel EV, Samocha KE, Banks E, Fennell T, et al. Analysis of protein-coding genetic variation in 60,706 humans. Nature. 2016;536(7616):285-91.

56. Curley JP, Champagne FA. Influence of maternal care on the developing brain: Mechanisms, temporal dynamics and sensitive periods. Frontiers in neuroendocrinology. 2016;40:52-66.

57. Pena CJ, Neugut YD, Champagne FA. Developmental timing of the effects of maternal care on gene expression and epigenetic regulation of hormone receptor levels in female rats. Endocrinology. 2013;154(11):4340-51.

58. Shonkoff JP, Phillips DA. From neurons to neighborhoods: The science of early childhood development. Washington, DC: National Academy Press; 2000.

59. Shonkoff JP, Richter L, van der Gaag J, Bhutta ZA. An integrated scientific framework for child survival and early childhood development. Pediatrics. 2012;129(2):e460-72.

60. Lieberman AF, Ghosh Ippen C, Van Horn P. Child-Parent Psychotherapy: 6-Month Follow-up of a Randomized Controlled Trial. Journal of the American Academy of Child \& Adolescent Psychiatry. 2006;45(8):913-8.

61. Ghosh Ippen C, Harris WW, Van Horn P, Lieberman AF. Traumatic and stressful events in early childhood: Can treatment help those at highest risk? Child Abuse \& Neglect. 2011;35(7):504-13.

62. Masten AS, Barnes AJ. Resilience in Children: Developmental Perspectives. Children (Basel). 2018;5(7).

63. Purewal Boparai SK, Au V, Koita K, Oh DL, Briner S, Burke Harris N, et al. Ameliorating the biological impacts of childhood adversity: A review of intervention programs. Child Abuse \& Neglect. 2018;81:82105.

64. Aghaee S, Deardorff J, Greenspan LC, Quesenberry CP, Kushi LH, Kubo A. Early life household intactness and timing of pubertal onset in girls: a prospective cohort study. BMC Pediatrics. 2020;20(1):464.

65. Daryanani I, Hamilton JL, Abramson LY, Alloy LB. Single Mother Parenting and Adolescent Psychopathology. Journal of Abnormal Child Psychology. 2016;44(7):1411-23.

66. Alami A, Khosravan S, Sadegh Moghadam L, Pakravan F, Hosseni F. Adolescents' self-esteem in single and two-parent families. Int J Community Based Nurs Midwifery. 2014;2(2):69-76.

67. Ellis BJ. Timing of pubertal maturation in girls: an integrated life history approach. Psychol Bull. 2004;130(6):920-58.

68. Smith KE, Pollak SD. Rethinking Concepts and Categories for Understanding the Neurodevelopmental Effects of Childhood Adversity. Perspectives on psychological science : a journal of the Association for Psychological Science. 2021;16(1):67-93. 
medRxiv preprint doi: https://doi.org/10.1101/2021.06.28.21259423; this version posted July 3, 2021. The copyright holder for this preprint (which was not certified by peer review) is the author/funder, who has granted medRxiv a license to display the preprint in perpetuity.

All rights reserved. No reuse allowed without permission.

69. Walton E. Epigenome-wide Associations With Attention-Deficit/Hyperactivity Disorder in Adults: The Need for a Longitudinal Life Course Approach in Epigenetic Psychiatry. Biological Psychiatry. 2019;86(8):570-2.

70. Chiu YH, Rifas-Shiman SL, Kleinman K, Oken E, Young JG. Effects of intergenerational exposure interventions on adolescent outcomes: An application of inverse probability weighting to longitudinal prebirth cohort data. Paediatr Perinat Epidemiol. 2020;34(3):366-75.

71. Slopen N, Shonkoff JP, Albert MA, Yoshikawa H, Jacobs A, Stoltz R, et al. Racial Disparities in Child Adversity in the U.S.: Interactions With Family Immigration History and Income. Am J Prev Med. 2016;50(1):47-56. 
Table 1. Top associations between time-dependent exposure to adversity and DNA methylation at age 15.

\begin{tabular}{|c|c|c|c|c|c|c|c|c|c|c|c|c|c|}
\hline Adversity & Timing & $\begin{array}{c}\text { Age at } \\
\text { adversity } \\
\text { (years) }\end{array}$ & CpG & $\begin{array}{l}\text { DNAm } \\
\text { unexp. }{ }^{1}\end{array}$ & $\begin{array}{c}\text { DNAm } \\
\text { exp. } \text { SP }^{2}\end{array}$ & $\begin{array}{c}\Delta \\
\text { DNAm }^{3}\end{array}$ & $\begin{array}{c}\text { Effect } \\
\text { estimate }^{4}\end{array}$ & $\mathbf{S E}^{*}$ & $\underset{\text { squared }}{\text { R- }}$ & P-value & FDR & $\begin{array}{l}\text { Nearest } \\
\text { gene }\end{array}$ & Trajectory class \\
\hline \multirow{2}{*}{$\begin{array}{l}\text { Caregiver } \\
\text { physical or } \\
\text { emotional abuse }\end{array}$} & Early childhood & 5 & cg15454534 & 0.885 & 0.867 & -0.018 & -0.018 & 0.003 & 0.045 & 9.52E-08 & $1.44 \mathrm{E}-02$ & OR2T1 & Latent graded \\
\hline & & & cg14855874 & 0.091 & 0.123 & 0.032 & 0.032 & 0.006 & 0.046 & $4.89 \mathrm{E}-08$ & $1.44 \mathrm{E}-02$ & BANK1 & Emergent \\
\hline \multirow{3}{*}{$\begin{array}{l}\text { Sexual or } \\
\text { physical abuse } \\
\text { (by anyone) }\end{array}$} & Early childhood & 3.5 & cg17928317 & 0.681 & 0.785 & 0.104 & 0.076 & 0.015 & 0.041 & $2.06 \mathrm{E}-07$ & $2.08 \mathrm{E}-02$ & MAGEC3 & Primed \\
\hline & & & $\operatorname{cg} 15723468$ & 0.822 & 0.779 & -0.043 & -0.045 & 0.009 & 0.041 & $1.89 \mathrm{E}-07$ & $2.08 \mathrm{E}-02$ & GALNT2 & $\begin{array}{l}\text { Latent sensitive } \\
\text { period }\end{array}$ \\
\hline & & & $\operatorname{cg} 26970800$ & 0.902 & 0.847 & -0.055 & -0.055 & 0.010 & 0.044 & 8.51E-08 & $2.08 \mathrm{E}-02$ & CBLIF & Emergent \\
\hline $\begin{array}{l}\text { Maternal } \\
\text { psychopathology }\end{array}$ & $\begin{array}{l}\text { Very early } \\
\text { childhood }\end{array}$ & 2.75 & cg16813552 & 0.898 & 0.883 & -0.015 & -0.015 & 0.003 & 0.045 & $7.11 \mathrm{E}-08$ & 2.15E-02 & $\overline{\text { OGA }}$ & Stable \\
\hline \multirow[t]{16}{*}{$\begin{array}{l}\text { One adult in the } \\
\text { household }\end{array}$} & $\begin{array}{l}\text { Very early } \\
\text { childhood }\end{array}$ & 1.75 & $\operatorname{cg} 05491478$ & 0.908 & 0.880 & -0.028 & -0.027 & 0.006 & 0.038 & $7.33 \mathrm{E}-07$ & $2.81 \mathrm{E}-02$ & DUSP10 & Overcompensation \\
\hline & Early childhood & 3.9 & cg01060989 & 0.824 & 0.794 & -0.031 & -0.031 & 0.005 & 0.047 & $6.73 E-08$ & $6.78 \mathrm{E}-03$ & LRRFIP1 & Latent graded \\
\hline & & & $\operatorname{cg} 06711254$ & 0.686 & 0.631 & -0.055 & -0.056 & 0.012 & 0.036 & $2.15 \mathrm{E}-06$ & $3.98 \mathrm{E}-02$ & FSIP2 & Flat emergent \\
\hline & & & cg08818094 & 0.847 & 0.798 & -0.048 & -0.050 & 0.008 & 0.051 & 8.79E-09 & 1.33E-03 & TBC1D19 & $\begin{array}{l}\text { Latent sensitive } \\
\text { period }\end{array}$ \\
\hline & & & $\operatorname{cg} 19096460$ & 0.845 & 0.821 & -0.024 & -0.024 & 0.005 & 0.035 & $2.89 \mathrm{E}-06$ & $4.85 \mathrm{E}-02$ & HERC3 & Latent graded \\
\hline & & & $\operatorname{cg} 15817130$ & 0.794 & 0.759 & -0.036 & -0.038 & 0.007 & 0.037 & $1.83 \mathrm{E}-06$ & $3.69 \mathrm{E}-02$ & MYO10 & Latent graded \\
\hline & & & $\operatorname{cg} 02584161$ & 0.661 & 0.603 & -0.057 & -0.058 & 0.011 & 0.038 & $1.28 \mathrm{E}-06$ & $3.42 \mathrm{E}-02$ & & Latent graded \\
\hline & & & $\operatorname{cg} 16907527$ & 0.853 & 0.824 & -0.030 & -0.032 & 0.005 & 0.060 & $4.17 \mathrm{E}-10$ & $1.26 \mathrm{E}-04$ & DSP & Flat emergent \\
\hline & & & $\operatorname{cg} 11811897$ & 0.758 & 0.711 & -0.047 & -0.047 & 0.010 & 0.037 & $1.68 \mathrm{E}-06$ & 3.64E-02 & VEGFA & $\begin{array}{l}\text { Latent sensitive } \\
\text { period }\end{array}$ \\
\hline & & & $\operatorname{cg} 15864691$ & 0.907 & 0.889 & -0.018 & -0.018 & 0.004 & 0.038 & $8.36 \mathrm{E}-07$ & $2.81 \mathrm{E}-02$ & PKD1L1 & Overcompensation \\
\hline & & & $\operatorname{cg} 04036644$ & 0.882 & 0.855 & -0.027 & -0.026 & 0.005 & 0.037 & $1.36 \mathrm{E}-06$ & $3.42 \mathrm{E}-02$ & HOXA10 & $\begin{array}{l}\text { Latent sensitive } \\
\text { period }\end{array}$ \\
\hline & & & $\operatorname{cg} 15783822$ & 0.868 & 0.848 & -0.021 & -0.021 & 0.004 & 0.039 & $8.08 \mathrm{E}-07$ & $2.81 \mathrm{E}-02$ & LOC 286083 & Latent graded \\
\hline & & & $\operatorname{cg} 02810291$ & 0.840 & 0.818 & -0.022 & -0.023 & 0.005 & 0.037 & $1.35 \mathrm{E}-06$ & $3.42 \mathrm{E}-02$ & CUX2 & Overcompensation \\
\hline & & & $\operatorname{cg} 15814750$ & 0.723 & 0.684 & -0.039 & -0.040 & 0.009 & 0.039 & $6.57 \mathrm{E}-07$ & $2.81 \mathrm{E}-02$ & STK38L & Latent graded \\
\hline & Late childhood & 10 & cg12096528 & 0.890 & 0.874 & -0.016 & -0.016 & 0.003 & 0.036 & $2.24 \mathrm{E}-06$ & $3.98 \mathrm{E}-02$ & PRR4 & Overcompensation \\
\hline & Accumulation & & cg10420609 & 0.559 & 0.522 & -0.037 & -0.014 & 0.003 & 0.039 & $7.71 \mathrm{E}-07$ & $2.81 \mathrm{E}-02$ & AKAP13 & Latent graded \\
\hline
\end{tabular}




$\begin{array}{lllllllllll}\operatorname{cg} 00807464 & 0.052 & 0.057 & 0.006 & 0.003 & 0.001 & 0.040 & 7.56 \mathrm{E}-07 & 2.81 \mathrm{E}-02 & \text { WDR72 } & \text { Stable } \\ \operatorname{cg} 14579651 & 0.634 & 0.605 & -0.028 & -0.012 & 0.002 & 0.037 & 1.68 \mathrm{E}-06 & 3.64 \mathrm{E}-02 & \text { SLC25A41 } & \text { Stable }\end{array}$

${ }^{1}$ DNAm unexp. = mean DNA methylation levels in individuals with no exposure to adversity from ages 0 to 11.

${ }^{2}$ DNAm exp. SP = mean DNA methylation levels in individuals with exposure to adversity that occurred during the selected sensitive period (SP). Accumulation hypotheses show the mean DNA methylation levels in those with at least one exposure to adversity.

${ }^{3} \Delta \mathrm{DNAm}=$ difference in mean DNA methylation levels between individuals exposed to adversity during the selected sensitive period and individuals unexposed to adversity (i.e., DNAm exp. SP - DNAm unexp.)

${ }^{4}$ Effect estimates were calculated using linear regression of exposure to adversity from the theoretical model and DNA methylation, correcting for the covariates described in the methods.

$* \mathrm{SE}=$ standard error; bolded loci passed a Bonferroni threshold of $\mathrm{p}<1.65 \times 10^{-7}$; Very early childhood $=0-3$ years, Early childhood $=$ 3-5 years; Late childhood = 8-11 years. 
medRxiv preprint doi: https://doi.org/10.1101/2021.06.28.21259423; this version posted July 3, 2021. The copyright holder for this preprint (which was not certified by peer review) is the author/funder, who has granted medRxiv a license to display the preprint in perpetuity.

Table 2. Types of DNAm trajectories and response to childhood adversity.

\begin{tabular}{llll}
$\begin{array}{l}\text { Trajectory } \\
\text { number }\end{array}$ & Trajectory name & $\begin{array}{l}\text { \# of } \\
\text { loci }^{1}\end{array}$ & $\begin{array}{c}\text { Sample } \\
\text { trajectory }\end{array}$ \\
\hline & Emergent & 2 &
\end{tabular}

Primary characteristics

Mean DNAm values stayed the same after age 7 , with differences in the exposed-SP group that appeared in childhood and fully emerged by age 15.

Mean DNAm values were the same from age 0 to 7 , with differences in the exposed-SP group that remained small throughout childhood and fully emerged by age 15 .

3

Overcompensation

4

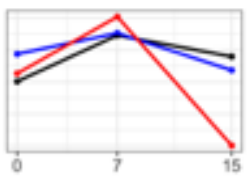

4

Latent graded

8

5

Latent sensitive period

\section{4}

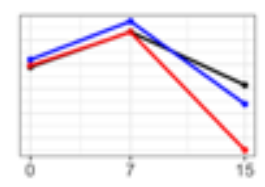

Mean DNAm values varied between timepoints, but not between exposure groups. Cross-over effects between exposed-SP and other groups were present from age 7 to age 15 .

Mean DNAm values varied between timepoints, and the exposed-other group showed graded differences in DNAm compared to other groups. The effects of childhood adversity during sensitive periods only fully emerged at age 15 .

Mean DNAm values varied between timepoints, the exposed-SP group showed differences from other groups, but the exposed-other group did not differ from the unexposed group. The effects of childhood adversity during sensitive periods only fully emerged at age 15 .

Mean DNAm values were the same from ages 0 to 7 , and no mean differences were observed between exposed-SP and exposed-other. Exposed-other were different from unexposed at age 0 and 7 , while exposed-SP were different from both groups at age 15 .

Slight differences were present between exposed-SP and unexposed individuals at age 7 , which fully

Stable (no group-by-age interaction)
3

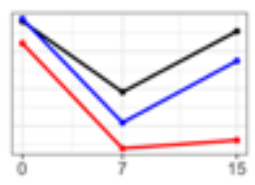

emerged by age 15 .

${ }^{1}$ Othe top 24 loci identified in the SLCMA of adversity between ages 0-11 and adolescent DNA methylation. 
medRxiv preprint doi: https://doi.org/10.1101/2021.06.28.21259423; this version posted July 3, 2021. The copyright holder for this preprint (which was not certified by peer review) is the author/funder, who has granted medRxiv a license to display the preprint in perpetuity.

All rights reserved. No reuse allowed without permission.

${ }^{2}$ Sample trajectories show the DNA methylation (DNAm) levels on the y-axis and the age at DNAm collection on the x-axis. Red trajectories represent the mean DNAm of those exposed to adversity during the period identified in the SLCMA (exposed-SP). Blue trajectories represent the mean DNAm of those exposed to adversity outside the period identified in the SLCMA (exposed-other). Black trajectories represent the mean DNAm of those with no exposure to adversity across development (unexposed). 


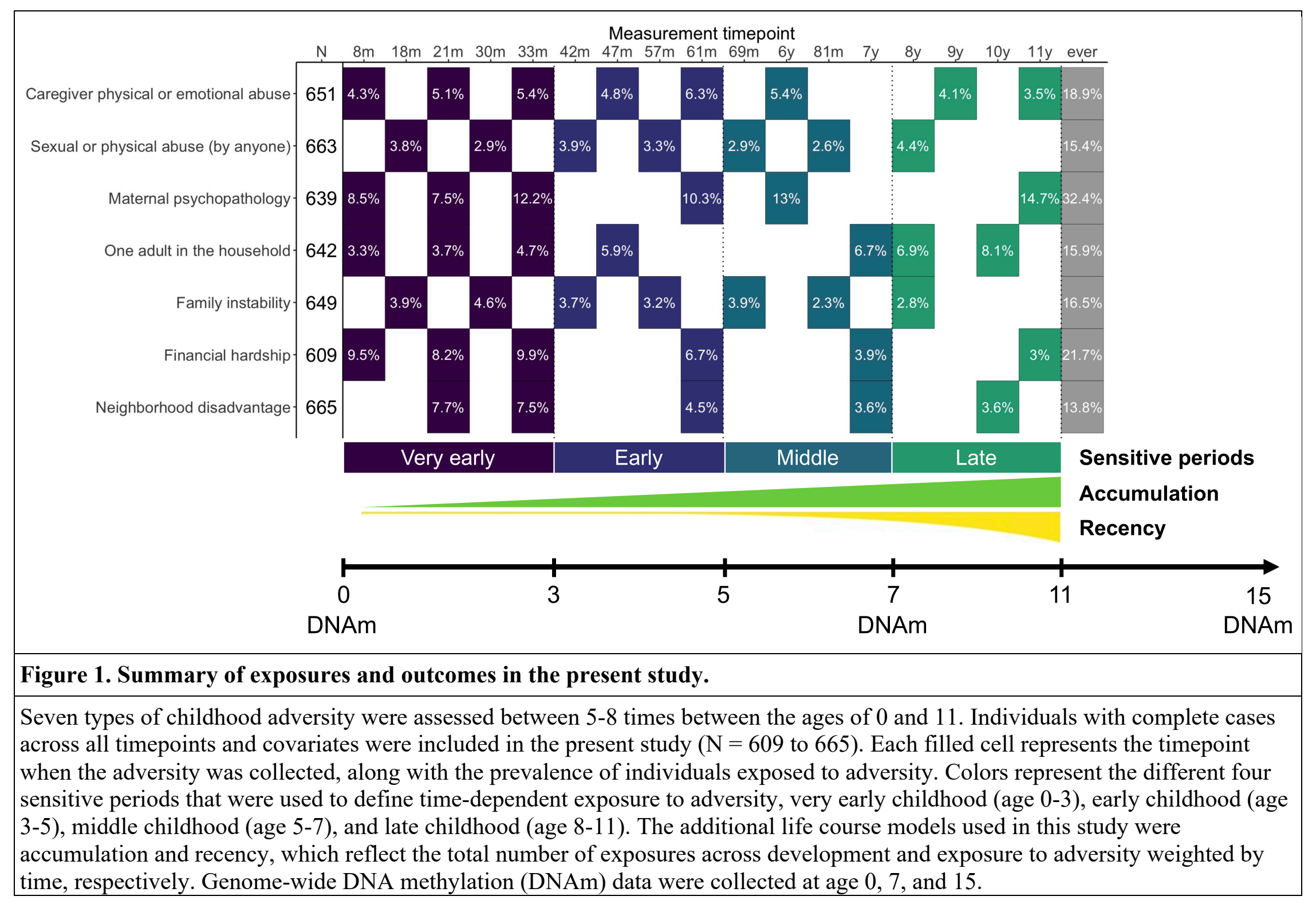




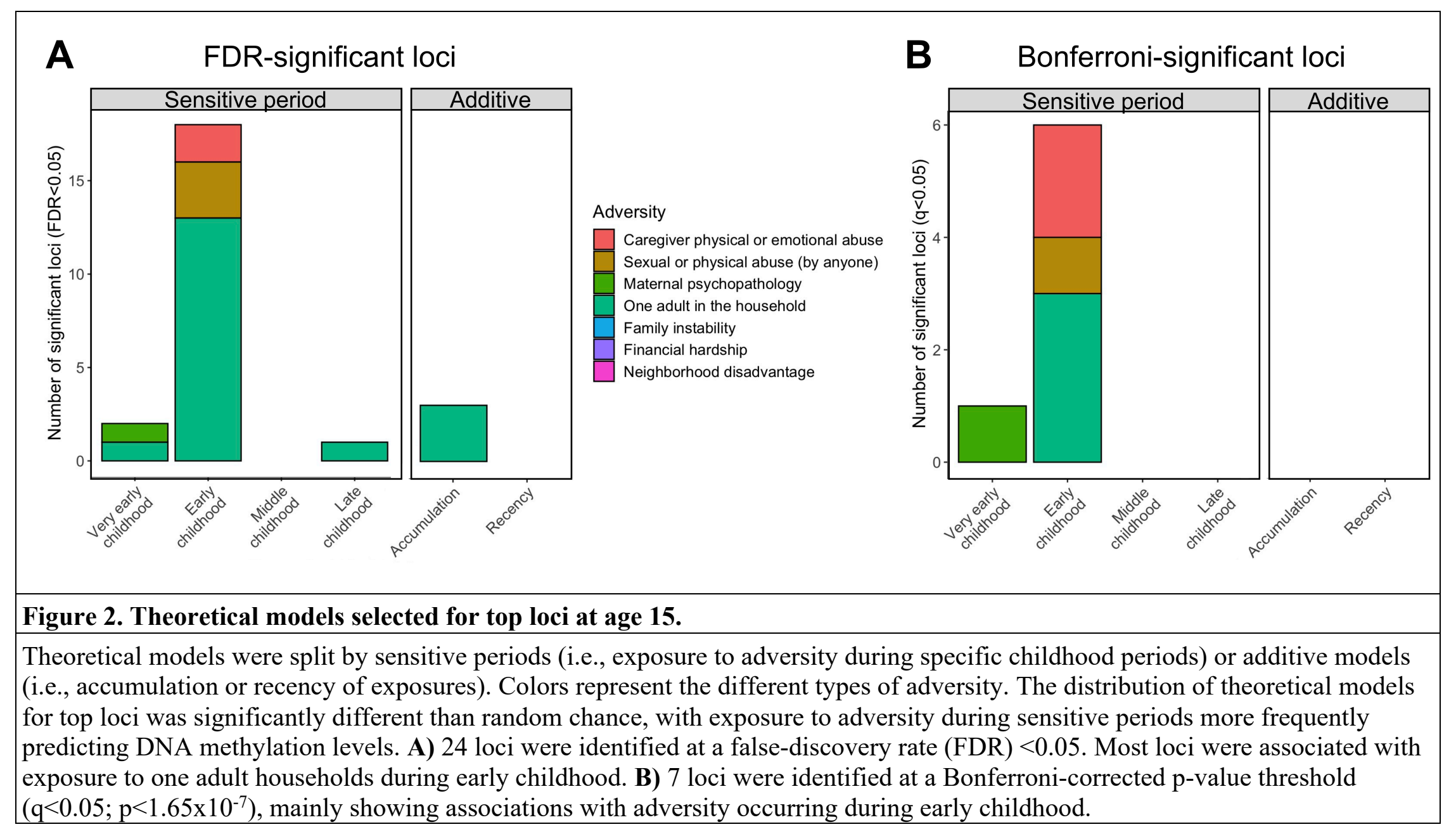


medRxiv preprint doi: https://doi.org/10.1101/2021.06.28.21259423; this version posted July 3, 2021. The copyright holder for this preprint (which was not certified by peer review) is the author/funder, who has granted medRxiv a license to display the preprint in perpetuity.

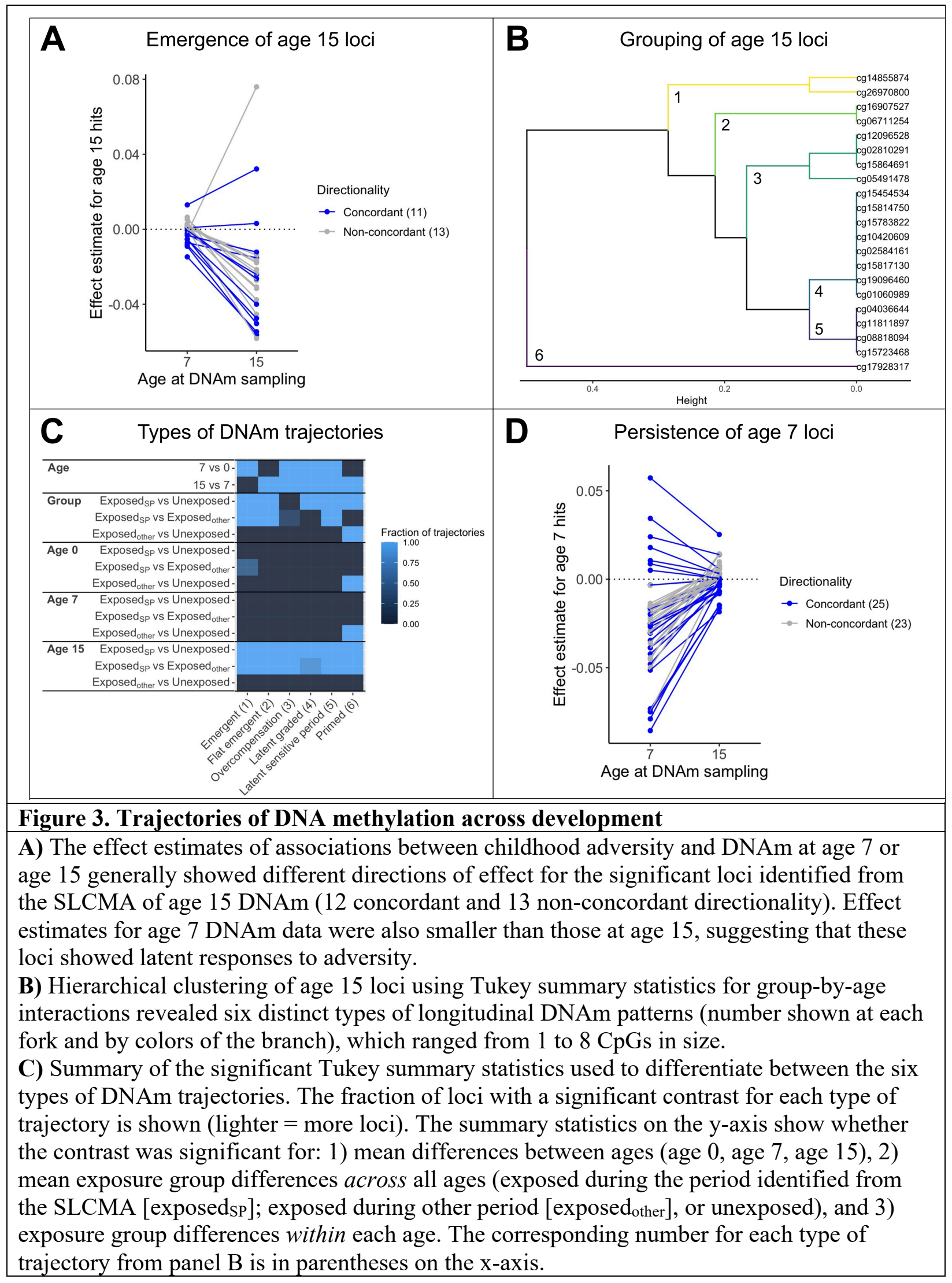


medRxiv preprint doi: https://doi.org/10.1101/2021.06.28.21259423; this version posted July 3, 2021. The copyright holder for this preprint (which was not certified by peer review) is the author/funder, who has granted medRxiv a license to display the preprint in perpetuity.

All rights reserved. No reuse allowed without permission.

D) The effect estimates of associations between childhood adversity and DNAm at age 7 or age 15 generally showed different directions of effect for the significant loci identified in a previous study of age 7 DNAm (25 concordant and 23 non-concordant directionality). Effect estimates for age 15 DNAm data were also smaller than those at age 7 , suggesting that these loci showed early responses to adversity that resolved by adolescence. 